\title{
25 麻醉器の保守・管理マニュアルについて（その1）
}

田中克己，久保 仁，釘宮豊城，小林寞伊，新井晴代，都築正和（東京大手術部）

目的：東大病院手術部では，麻醉器および麻酔関連 器材をより安全かつ確実に取り扱うことを目的として, マニュアルの作成を検討してきた．今回その第 1 次案 がまとまったので報告する.

内容：マニュアルの第 1 項は, 使用および定期点検 に関するものである.

(1) 日常点検

電源・供給ガスのチェック．流量計・酸素濃度計の チェック．麻酔剤の補充．炭酸ガス吸収剂の交换. 回
路フィルターの交換. 一方向弁の作動確認. リークテ ストなど簡潔なもので, 使用前と使用後に行われる.

(2) 定期点検

回路部のダイヤフラム・キャップ・パッキンのチェ ック．炭酸ガス吸収装置そのものの破損やリークのチ エック，ガス供給部の接続のチェックなどで，日常点 検では不十分なものを点検する. 2 週間に一度行って いる、アゼプターによる殺菌・消毒の時に併せて行っ ている.

\section{6. 麻酔器の保守・管理マニュアルについて（その 2）}

久保 仁，田中克己，鎬宮賗城，小林寛伊，新井晴代，都築正和（東京大手術部）

目的: 東大病院手術部では, 麻酔器および麻酔関連 器材をより安全かつ確実に取り报うことを目的として， マニュアルの作成を検討してきた. 今回その第 1 次案 がまとまったので報告する.

マニュアルの内容 : マニュアルの第 2 項は, 感染性 患者への対応と, その手術後の麻酔器および麻酔関連 器材の処理法に関するものである. その内容は,

1) ディスポーザブル器材の活用

今日の滅菌・消毒法によれば, 理論的詨匛容易で あるが，人員と時間とに制限がある現状では，必ずし も理想論通りにはいかない. 従って細菌フィルタの使 用や, ディスポーザブル製品で対応しうる部分は, 可
能な限り使い捨て処理をした.

2) 麻酔器・ベンチレーターの殺菌

3 週間に 1 回，ホルムアルデヒドガス殺菌（アゼプ ター®使用) を行うことを原則とし, $\mathrm{HBe}$ 抗原陽性患 者, メチシリン耐性黄色ブドウ球菌感染患者, AIDS 患者などに使用した際には, 即時ホルムアルデヒドガ ス殺菌を行うこととした.

しかし殺菌可能な台数には限界があり，また天井椇 垂型麻醐器に対する対応も問題として残った.

表面の消毒には, グルタラール，次亜塩素酸ナトリ ウムなどを用いるようにした. 